\title{
INFORMATION AND COMMUNICATION TECHNOLOGIES (ICT) IN BANKING SECTOR
}

\author{
AGNIESZKA BUDZIEWICZ-GUŹLECKA, ${ }^{1}$ MARIUSZ WOŹNIAKOWSKI ${ }^{2}$ \\ ${ }^{1}$ University of Szczecin, Faculty of Management and Economics Services, POLAND \\ e-mail: agnieszka.budziewicz@wzieu.pl \\ ${ }^{2}$ University of Lodz, Faculty of Management, POLAND \\ e-mail: mariusz.wozniakowski@uni.lodz.pl
}

RECEIVED

ACCEPTED

JEL

CLASSIFICATION

KEYWORDS

ABSTRACT
6 November 2018

3 December 2018

$\mathrm{G} 21,016,035$

ICT, information, bank, Internet communication, social media

Information transformation has its source in the development of information technologies including software, social networks, data resources and the collection and dissemination of information. Technology also affects banks. The aim of the article is an attempt to recognize the use of modern tools by commercial banks operating in Poland. The conducted analysis showed to what extent banks in Poland use selected solutions of modern technologies.

\section{Introduction}

Information transformation has its source in the development of information technologies including software, social networks, data resources and the collection and dissemination of information. Thus, information and communication technology has become a key determinant of development and ensuring competitiveness also for banks (Radnan, Purba, 2016, p. 283). Banks have a wide range of possibilities to use modern tools. The aim of the 
article is an attempt to recognize the use of modern tools by commercial banks operating in Poland. The article presents the following research hypothesis - banks operating in Poland actively use tools that fit into the concept of modern technologies. In reference to the assumed goal and adopted hypothesis, the article poses the following research question - what banks in Poland are pioneers in the implementation of modern tools? In an attempt to answer the question, the article first addresses the changes in the financial market and aspects of access to the Internet in Poland in connection with the issue of digital exclusion. It is followed by an in-depth audit analysis presented in two areas. The first is the use of social media. The second is modern access channels to banking for customers. The conducted analysis showed to what extent banks in Poland use selected solutions of modern technologies.

\section{Selected aspects of changes in the financial market in the aspect of social exclusion}

Current banks have to face the challenges of modern techniques and technologies, which changes the perception and behaviour of the bank. There is an intense transformation from the bank of the twentieth century into the bank of the 21 st century, the basic characteristics of banks change, which is presented in Table 1.

Table 1. Basic characteristics of banks in the 20th and 21st centuries

\begin{tabular}{|c|c|c|}
\hline & Bank of the 20 th century & Bank of the 21st century \\
\hline \multirow{2}{*}{ Contact with customer } & physical & digital \\
\hline & paper & data, information \\
\hline \multirow{3}{*}{ Resources } & human and material resources (e.g. buildings) & servers, software, know-how \\
\hline & capital-intensive & cheap \\
\hline & closely connected & loosely connected \\
\hline Functioning & proprietary, free & standardised, swift \\
\hline Regulations & perceived as limitations & perceived as a factor facilitating functioning \\
\hline Access & temporary & without time limits \\
\hline
\end{tabular}

Source: study based on: The New Bank... (2018).

Changes in bank characteristics result from dynamically developing techniques and technologies of information transfer. This causes changes in the society which as an information society is increasingly using the Internet, and thus modern services. The development of Internet access technology leads to the development of services performed via the Internet. Every year, the number of individuals who have never used the Internet falls in Poland. This decrease is presented in Figure 1.

As it can be seen, individuals who had never used the Internet accounted for 19.6\% in 2017 (compared to $32.7 \%$ in 2011) thus the number of such people is definitely decreasing. On the other hand, there is an increase in the number of users who do not only use the Internet but do it every day. Over the years, we can see a sharp increase in daily internet users in Poland. In 2010, people using the Internet every day constituted $54.6 \%$, while in 2017 this number increased to $72.7 \%$.

More frequent use of the Internet translates into an increase in the popularity of using online banking. The number of online banking users in Poland is shown in Figure 2. 


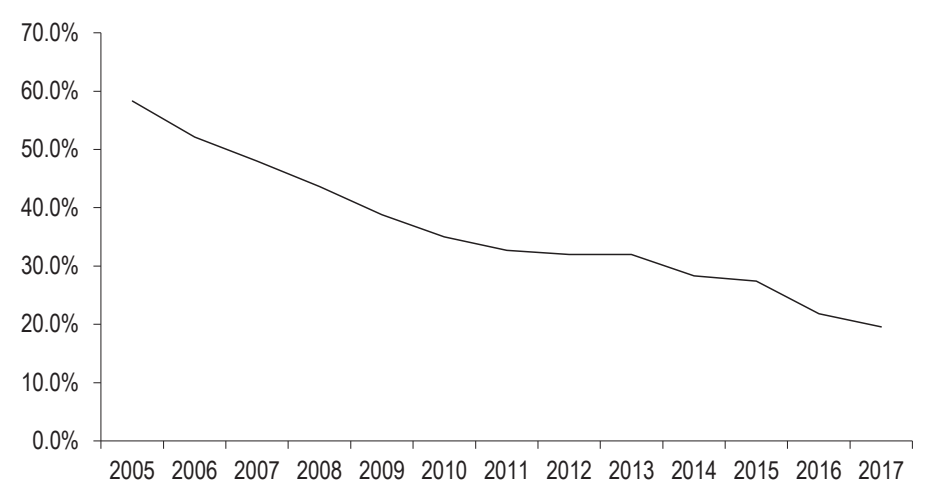

Figure 1: Individuals who have never used the Internet in Poland

Source: study based on the DESI report

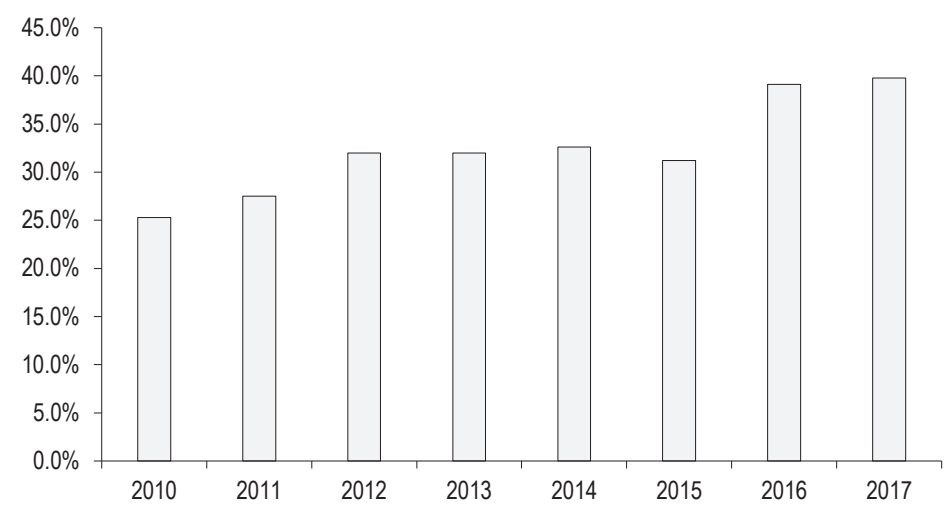

Figure 2. Number of online banking users in 2010-2017

Source: own study based on the DESI report.

The number of online banking users in Poland is gradually growing. In 2017, it was 39.8\%, while in 2010 this figure was at $25.3 \%$. The slow growth of online banking users results from concerns about the security of financial resources, which is why the awareness and knowledge of current and potential users are very important.

Part of society is socially excluded for various reasons. If members of the public are not able to use modern information transfer technologies or use information, then exclusion takes the form of a digital exclusion.

The main reason for social exclusion is not only a lack of access to electronic communication services but also a lack of the ability to use services in the information society. Lack of ability to use services based on information transfer technologies is called digital exclusion. The use of digital technologies requires appropriate social competences and knowledge. That is why education from an early age is that important as a way to prevent digital exclusion. 
This knowledge concerns not only the security of using online banking, but also emerging new financial services. Due to the expansion of the offer and the increase in the complexity of financial services as a result of the implementation of innovative IT and communication solutions, knowledge of finance is becoming more and more important (Kuchciak, 2013, p. 66). Visible in recent years, the dynamic development of information and telecommunications technologies covers more and more new areas of social and economic activity, such as the dynamic development of the sharing economy (Budziewicz-Guźlecka, 2017). A new model of banking "cyber-customer" is emerging, someone who needs intelligent financial services which are to support specific consumer needs in the least absorbing way (consumerisation of banking). Progress in this area is huge (convenience, availability and personalization of retail services, artificial intelligence, biometrics, geolocation, etc.), though still very fragmentary (E\&Y Report). In search of a competitive advantage, banks began to pay attention to the importance of various distribution channels. The social aspect is also important. Wide access to financial services is correlated with the broadly understood social commodity and the benefits of individuals.

\section{Modern banking access channels for customers}

The Internet has become an integral part of the solutions used by banks. Banks change the concept of customer service by differentiating distribution channels. The development of information technologies means that banks try to win customers through electronic distribution channels.

One of the modern solutions based on the Internet, which is used by banks is social media. Social media is a convenient and useful way to build interaction and cooperation with Internet users in the aspect of creating new information and acquiring knowledge (Levy, 2009, p. 120; Felix, Rauschnabel, Hinsch, 2017, p. 118). The use of various social networking sites allows for reaching to different clients, including those whose custom to use the selected social networking site in private life translates into a desire to use this site in their contacts with the bank. The greater the diversity of networking sites in each bank, the greater the chance of reaching potential customers, thus preventing digital exclusion, and leading to the situation of digital inclusion.

\section{Analysis of hanks in terms of the use of modern information and communication technologies}

For the purposes of market analysis in the area of using modern information and communication technologies, the banks operating in Poland were selected. A list by the Polish Financial Supervision Authority (KNF, 2018) was used - of commercial banks operating in the form of joint-stock companies (as of Q3 2018). According to KNF data, there are 34 banks in Poland that meet these criteria, however, only 33 entities were analyzed further as on August 1 BPI Bank Polskich Inwestycji SA was taken over by Getin Noble Bank. The selected banks were audited in two areas. The first is the use of social media. The second is the use of modern technologies in customer access channels to banking. The study was carried out on October 16-18, 2018.

The first area was analyzed in three stages:

1. The banks' websites were checked to determine to which social media they offer a direct forwarding (e.g. in the form of social plug-ins, classic hyperlinks, etc.). In the absence of a direct reference to a social media profile in the structure of the website, the profiles were searched for in Google web browser, by entering the relevant phrase, e.g. ING Instagram, mBank Twitter, etc. This way of looking for profiles was applied to the five most popular social websites: Facebook, YouTube, Instagram, Twitter and Linkedln. 
2. The profiles in social networks or other media (e.g. blogs) identified in the two previous steps were analyzed in terms of content. Only profiles kept in the Polish language were taken into account, due to the target recipient - the client from the Polish market. The most important thing was checking the tone of communication (e.g. commercial - presentation of the offer, press releases, education, etc.) and whether the profiles are constantly updated.

In the second area, it was checked what ICT solutions were used by the analyzed 33 entities (Tab. 3). Only those tools were included that were directly related to the bank's website (provided that the site was maintained in the Polish language) or they were referred to in the structure of the website, or the website contained information as to where they can be found elsewhere in the network and/or in the real world. It was established which banks use the following information and communication technologies:

1. Responsive website (designed in accordance with the principles of responsive web design).

2. The e-banking module.

3. Applications for mobile banking service for customers divided into operating systems Android, IOS and other.

4. Search engine / locator of outlets divided into: individual customer/corporate customer, private banking, ATMs/cash deposit machines and other.

5. Contact with the bank via the contact form, call centre, IVR, chat, video chat and other.

6. Newsletter for any subscriber, i.e. not only a customer who has given marketing consent to receive commercial information by email.

7. Other (e.g. loyalty program, cross-promotions offered with bank partners, etc.).

Table 2. Bank profiles on social networking websites (as on 18/10/2018)

\begin{tabular}{|c|c|c|c|c|c|c|c|c|}
\hline \multirow{2}{*}{ No. } & \multirow{2}{*}{ Name of the Bank } & \multicolumn{5}{|c|}{ Social media plugins on the banks' websites } & \multirow{2}{*}{$\begin{array}{l}\text { Corporate } \\
\text { blog }\end{array}$} & \multirow{2}{*}{ Tota } \\
\hline & & Facebook & YouTube & Instagram & Twitter & Linkedln & & \\
\hline 1 & 2 & 3 & 4 & 5 & 6 & 7 & 8 & 9 \\
\hline & Alior Bank & + & + & & + & + & & 4 \\
\hline 2. & Bank BGŻ BNP Paribas & + & + & $(+)$ & & + & & 4 \\
\hline & Bank BPH & & & & & $(+)$ & & 1 \\
\hline 4. & Bank Handlowy w Warszawie & + & + & + & + & + & & 5 \\
\hline & Bank Millennium & + & + & $(+)$ & + & + & & 5 \\
\hline 6. & Bank Ochrony Środowiska & + & $(+)$ & & + & + & & 4 \\
\hline 7. & Bank Pocztowy & + & + & & $(+)$ & $(+)$ & & 4 \\
\hline 8. & Bank Polska Kasa Opieki & + & + & + & + & + & & 5 \\
\hline 9. & Bank Polskiej Spółdzielczości & + & + & $(+)$ & & + & & 4 \\
\hline & Credit Agricole Bank Polska & + & + & + & & + & + & 5 \\
\hline 11. & Deutsche Bank Polska & & & & & $(+)$ & & 1 \\
\hline 12. & DnB Bank Polska & & & & & + & & 1 \\
\hline 13. & Euro Bank & + & + & + & + & $(+)$ & & 5 \\
\hline 14. & FCA-Group Bank Polska & & & & & + & & 1 \\
\hline 15. & Getin Noble Bank & + & + & + & & + & & 4 \\
\hline 16. & HSBC Bank Polska & & & & & & & 0 \\
\hline 17. & Idea Bank & + & + & + & + & + & & 5 \\
\hline 18. & ING Bank Ślaski & + & + & + & + & + & + & 6 \\
\hline 19. & mBank Hipoteczny & $(+)$ & & & & $(+)$ & & 2 \\
\hline
\end{tabular}




\begin{tabular}{|c|c|c|c|c|c|c|c|c|}
\hline 1 & 2 & 3 & 4 & 5 & 6 & 7 & 8 & 9 \\
\hline 20. & mBank & + & + & + & + & $(+)$ & + & 6 \\
\hline 21. & Mercedes-Benz Bank Polska & + & + & + & + & + & & 5 \\
\hline 22. & Nest Bank & & $(+)$ & & & + & & 2 \\
\hline 23. & Pekao Bank Hipoteczny & & & & & & & 0 \\
\hline 24. & PKO Bank Hipoteczny & & + & & & $(+)$ & & 1 \\
\hline 25. & Plus Bank & + & + & & + & $(+)$ & & 4 \\
\hline 26. & Powszechna Kasa Oszczędności Bank Polski & + & + & $(+)$ & + & + & + & 6 \\
\hline 27. & Raiffeisen Bank Polska & + & & & + & + & & 3 \\
\hline 28. & RBS BANK (Polska) & & & & & & & 0 \\
\hline 29. & Santander Bank Polska & + & + & + & + & + & + & 6 \\
\hline & Santander Consumer Bank & + & + & & & + & + & 4 \\
\hline & SGB-Bank & & $(+)$ & & & & & 1 \\
\hline & Toyota Bank Polska & & + & & & & & 1 \\
\hline 33. & Volkswagen Bank Polska & + & & & & & & 1 \\
\hline Total & & $21(22)$ & $20(23)$ & $10(14)$ & $14(15)$ & $19(27)$ & 6 & 107 \\
\hline
\end{tabular}

Explanation: " + " = profile to which there is a social plug-in on the website; $(+)=$ profile searched by Google search engine (no plug-in on the company website).

Source: own study.

Out of 33 analyzed banks, one (RBS Bank, part of the Royal Bank of Scotland group) does not have a website in Polish. In the case of the others, also one bank (HSBC Bank Polska) does not have any profile in social media for Polish-speaking customers, while Mercedes-Benz Bank uses the same profiles as for the car brand. 27 banks have in the structure of their own website a minimum one plug-in for their own profiles on social networking sites (for a detailed list see Table 2). 21 sites have links to Facebook, 20 - to YouTube, 19 - to Linkedln, 14 - to Twitter and 6 - to Instagram. In 6 cases there are also redirections to the company blog.

After the second stage of the study, further bank profiles were identified on social networking sites (there were no links from the company website level): 8 - to Linkedln, 4 - to Instagram, 3 - to YouTube and 1 - to Facebook and Twitter. In the end, it turned out that 2 banks do not have even one company profile on any social network. In other cases, the most popular networking site was Linkedln, followed by YouTube; in the most popular social networking site in the world - Facebook, 22 banks had their profiles. In turn, 15 profiles functioned on Twitter, and 14 - on Instagram.

All company profiles of banks on Linkedln contain their descriptions and news related to human resources issues, such as reports from job fairs, information about internship programs, student practices, employer branding activities, etc. Most banks also present current job offers and/or internships/student placements.

The Facebook profiles identified in the study are constantly updated. They present mainly the following contents: offer of banks (e.g. promotional interest rates on savings accounts, loans, etc.), organizational issues (e.g. interruptions in access to electronic banking), information on sponsoring activities or other activities related to corporate social responsibility, promotion of new forms of payments (e.g. Blik, Google Pay), security rules in electronic banking, encouraging regular savings. As the element activating Internet users, most often appear surveys which are to provoke fans of the profile to a discussion.

23 of the analyzed banks have own channels on YouTube, although in the case of SGB-Bank there is no content on it. On the other channels, the videos have been grouped into themed playlists. Among the dominant 
topics appeared: home finances, electronic banking manuals, promotion (advertising spots, known from television, sometimes in the extended version), CSR.

15 banks have own profile on Twitter. Due to the characteristics of this site, short messages prevail among posts (so-called tweets). This website is more often used for communication with investors and journalists rather than with customers and may contain many repetitions of Facebook content. Quite often it is a tool related to the press office.

In the next analyzed social network - Instagram, 14 banks have their profiles. In the case of this website, it is important to focus on visual content, minimally invasive when it comes to commercial content, hence posts related to sponsoring or other CSR activities, contests, promotional offers, discounts at bank partners, etc. Interesting content, going beyond the aforementioned subject of posts, is shown by Idea Bank which presents the Idea Hub project - the idea of co-working - a shared office space for bank customers, which is offered in 6 Polish cities (Warsaw, Łódź, Kraków, Wrocław, Poznań and Katowice).

Among the blogs run by banks, devoted to the issues of banking, economics, home budget management, saving, etc., it is worth paying attention to the PKO BP project - Szkolne Blogi (szkolneblogi.pl) - a blog platform of school savings banks, which familiarises users with the idea of the program dedicated to schools, announces competitions, presents curiosities from "the world of children's finances" and which is a perfect example of the fight against potential digital and financial exclusion through education from an early age.

Table 3. Information and communication technologies in banks

\begin{tabular}{|c|c|c|c|c|c|c|c|c|c|c|c|c|c|c|}
\hline \multirow[b]{2}{*}{ No. } & \multirow[b]{2}{*}{ Name of the bank } & \multirow[b]{2}{*}{$\sum_{\text {i }}^{0}$} & \multirow[b]{2}{*}{ 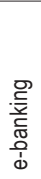 } & \multicolumn{2}{|c|}{ Applications } & \multirow{2}{*}{ 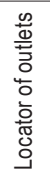 } & \multirow{2}{*}{ 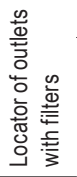 } & \multicolumn{5}{|c|}{ Contact } & \multirow[b]{2}{*}{ 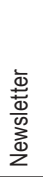 } & \multirow[b]{2}{*}{$\begin{array}{l}\stackrel{ \pm}{ \pm} \\
\stackrel{ \pm}{0}\end{array}$} \\
\hline & & & & 으 & 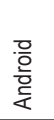 & & & 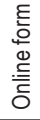 & 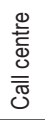 & $\stackrel{\underline{x}}{\geq}$ & $\frac{\widetilde{N}}{U}$ & $\begin{array}{l}\frac{\pi}{0} \\
\frac{\pi}{0} \\
\text { ष } \\
\frac{0}{5}\end{array}$ & & \\
\hline 1 & 2 & 3 & 4 & 5 & 6 & 7 & 8 & 9 & 10 & 11 & 12 & 13 & 14 & 15 \\
\hline 1. & Alior Bank & + & + & + & + & + & + & + & + & + & & & & + \\
\hline 2. & Bank BGŻ BNP Paribas & + & + & + & + & + & + & + & + & & + & & & \\
\hline 3. & Bank BPH & + & + & & & & & & + & & & & & \\
\hline 4. & Bank Handlowy w Warszawie & + & + & + & + & + & + & & + & & + & & & + \\
\hline 5. & Bank Millennium & + & + & + & + & + & + & + & + & + & + & & & + \\
\hline 6. & Bank Ochrony Środowiska & + & + & + & + & + & + & + & + & & & & & \\
\hline 7. & Bank Pocztowy & + & + & & & + & + & + & + & + & + & + & & \\
\hline 8. & Bank Polska Kasa Opieki & & + & + & + & + & + & + & + & & + & + & & \\
\hline 9. & Bank Polskiej Spółdzielczości & + & + & + & + & + & + & & + & + & & & & \\
\hline 10. & Credit Agricole Bank Polska & + & + & + & + & + & + & + & + & & & & + & + \\
\hline 11. & Deutsche Bank Polska & & + & & & + & + & + & + & + & & & & \\
\hline 12. & DnB Bank Polska & + & + & & & + & + & + & + & & & & & \\
\hline 13. & Euro Bank & + & + & + & + & + & + & + & + & + & & & & \\
\hline 14. & FCA-Group Bank Polska & + & & & & + & & + & + & & & & & \\
\hline 15. & Getin Noble Bank & + & + & + & + & + & + & + & + & & & & & \\
\hline 16. & HSBC Bank Polska & + & + & + & + & & & + & + & & & & & \\
\hline 17. & Idea Bank & + & + & + & + & + & + & + & + & & & & & \\
\hline 18. & ING Bank Śląski & + & + & + & + & + & + & + & + & & + & & & + \\
\hline 19. & mBank Hipoteczny & & & & & & & & & & & & & \\
\hline 20. & mBank & + & + & + & + & + & + & + & + & + & + & + & & + \\
\hline
\end{tabular}




\begin{tabular}{|c|c|c|c|c|c|c|c|c|c|c|c|c|c|c|}
\hline 1 & 2 & 3 & 4 & 5 & 6 & 7 & 8 & 9 & 10 & 11 & 12 & 13 & 14 & 15 \\
\hline 21. & Mercedes-Benz Bank Polska & + & & & & + & & + & & & & & & + \\
\hline 22. & Nest Bank & + & + & + & + & + & + & + & + & + & & + & & \\
\hline 23. & Pekao Bank Hipoteczny & & & & & & & & + & & & & & \\
\hline 24. & PKO Bank Hipoteczny & + & & & & & & & + & & & & & \\
\hline 25. & Plus Bank & + & + & + & + & + & + & + & + & & & & & + \\
\hline 26. & Powszechna Kasa Oszczędności Bank Polski & + & + & + & + & + & + & + & + & & & & + & \\
\hline 27. & Raiffeisen Bank Polska & + & + & + & + & + & + & + & + & & + & & & + \\
\hline & Santander Bank Polska & + & + & + & + & + & + & + & + & & + & + & + & \\
\hline & Santander Consumer Bank & + & + & & & + & + & + & + & & & & & \\
\hline & SGB-Bank & + & + & & & + & + & + & + & & & & & + \\
\hline & Toyota Bank Polska & + & + & & & + & & + & + & & & & & \\
\hline & Volkswagen Bank Polska & + & + & & & + & & & + & & & & & \\
\hline Tota & & 28 & 27 & 19 & 19 & 27 & 23 & 25 & 30 & 8 & 9 & 5 & 3 & 9 \\
\hline
\end{tabular}

Source: own study.

Out of 32 analyzed bank websites (RBS Bank does not have a website in Polish), 28 are responsive, i.e. they are designed so that their appearance and layout automatically adjust to the size of the browser window without damaging the visual plane and presented content, which is especially important in the era of accessing the Internet by customers by means of various devices (computer, tablet or smartphone). 27 banks have their own online banking module. Mortgage banks and two banks dependent on car brands do not offer this module, which is certainly related to the specifics of their offer, and thus the lack of the need to create a platform for e-banking.

Banks that provide services via the Internet in their majority (19 entities) offer their customers mobile applications, prepared with the aim of providing banking services to customers using smartphones. All offered applications are available for the most popular operating systems for mobile devices - Android and IOS. In several cases (Millennium, Pekao, Credit Agricole, Getinbank, HSBC, ING, PKO BP) an application for Windows Phone is also offered.

The basic locator of bank branches offers on its website 27 analyzed entities, of which in 23 cases it was possible to filter the search criteria, among others, for individual/corporate customer service, private banking, and ATMs/cash deposit machines. Interesting are filters "open on Saturdays" and "open on Sundays" (Euro Bank), "Idea Hub" (Idea Bank), "service in sign language" and "facilities for the disabled" (ING). In the case of car banks, the branch locator referred to the search for dealers of a given brand or brands whose products are financed by individual banks.

Banks give their current and potential customers a range of contact options. In this case, the most popular form is the helpline which is offered by 30 analysed banks. For those who abstain from the call centre, 25 banks offer contact forms, wherein in each case, it is possible to send a request for feedback in the form of an email, and in a few cases customers can leave their phone number so that a consultant could call them back. 8 banks inform customers on their websites about the implemented IVR systems (Interactive Voice Response) enabling the interactive service of the caller. It can be said that IVR has the functionality of an automatic call centre (Ellway, 2016, p 386). These banks provide schemes of their systems so that customers can check what they should select by dial tone (number, sign) on the telephone keypad in order to settle the matter that interests them. Most banks with call 
centres probably use IVR systems in some form, but they do not inform about it on their company website. In order to verify the actual situation, it would be necessary to connect with each helpline separately.

9 banks offer their customers a chat option, and 5 allow video chatting, of which Bank Pocztowy, ING, mBank and Santander also in sign language.

Another tool, a newsletter for any subscriber, i.e. not only a customer who has given marketing consent to receive commercial information by email (in fact, most customers using online banking receive email messages with commercial content from their banks) is offered by 3 banks. Most often, newsletters contain information about the bank's current offer, offers from partner companies, news from the bank's life and CSR information.

9 banks also offer other solutions in the field of information and communication technologies. Among them are various loyalty programs (most often associated with the use of credit cards) and a search tool for cars available off-the-shelf (car banks). Interesting is the Goodie app, created by Bank Millennium. It is a modern, free mobile application and a website in which users can find coupons, discounts, promotions, sales and discount codes. If the user is looking for a specific product in the newsletter with promotions of his favourite every day shop, the Goodie app will find it at the best price in the shop in the immediate area. With Goodie, customers can compare prices in newsletters of all major stores. Additionally, they can watch selected brands and receive push notifications with special offers and discounts as well as events in shopping malls (https://goodie.pl/o-goodie).

\section{Conclusions}

Access to and use of financial products and services has both social and economic significance. Socioeconomic development is accompanied by the development of the financial sector, and this development is accompanied by the dynamic development of modern technologies.

The conducted analysis showed to what extent banks operating in Poland use selected modern solutions in the field of information and communication technologies. The study showed that commercial banks operating in Poland are quite actively using social media in communication with particular stakeholder groups, mainly with customers. From the point of view of marketing communication, information about own profiles can be conveyed via own website (through dedicated plug-ins) and on different profiles mutually by conducting so-called cross-media activities. The most common mistake that occurred was too many promotional posts and not enough actions aimed at interacting with customers. It was also observed that the banks which largely target their activities to an individual customer are much more active both in the area of social media and using other modern tools presented that facilitate or diversify the ways in which customers communicate and use banking.

\section{References}

Budziewicz-Guźlecka, A. (2017). Role of the sharing economy in the contemporary economy. Ekonomiczne Problemy Usług, 126 (T. 1), 27-36.

Ellway, B. (2016). What's wrong with IVR system service? A spatial theorisation of customer confusion and frustration. Journal of Service Theory and Practice, 26 (4), 386-405.

Felix, R., Rauschnabel, P., Hinsch, C. (2017). Elements of strategic social media marketing: A holistic framework. Journal of Business Research, 70, 118-126.

https://ec.europa.eu/digital-single-market/en/desi.

https://goodie.pl/o-goodie. 
KNF (2018). Banki w formie spółek akcyjnych. Retrieved from: https://www.knf.gov.pl/podmioty/Podmioty_sektora_bankowego/ Banki_w_formie_spolek_akcyjnych.

Kuchciak, I. (2013). Kreowanie świadomości finansowej wyzwaniem konkurencyjności w niesprzyjającym otoczeniu. Zarządzanie i Finanse, 11 (4), 65-82.

Levy, M. (2009). Web 2.0 Implications on Knowledge Management. Journal of Knowledge Management, 13 (1), 120-134.

Managing change and risk in the age of digital transformation. The digital journey of financial institutions in ASEAN, E\&Y Report, Singapore 2016.

Radnan, P., Purba, J. (2016). The use of information communication technologies (ICT) as the technology acceptance model (TAM) of mobile banking. Journal Manajemen dan Pemasaran, 9 (2), 283-297.

The New Bank is $100 \%$ different to the Old Bank (2018). Skinner Blog. Retrieved from: https://thefinanser.com Digital Bank

Cite this article aS: Budziewicz-Guźlecka, A., Woźniakowski, M. (2018). Information and communication technologies (ICT) in banking sector. European Journal of Service Management, 4 (28/1), 39-48. DOI: 10.18276/ejsm.2018.28/1-05. 